\title{
From the Classroom to the Boardroom: The Impact of Information Literacy Instruction on Workplace Research Skills \\ By Tiffini Travis
}

"Many businesses are knowledge driven. Even entry level employees have to know how to identify information problems and go about solving them" $\sim$ unidentified employer 2000.

Topsey Smalley, Workplace Quotes

www.cabrillo.edu/ tsmalley/WorkplaceQuotes.html

\section{Introduction}

Since the wide-scale adoption of the ACRL Information Literacy Standards (2000), there have been numerous students who have graduated from universities that have formal library instruction programs. Currently there has been very little assessment of their post-graduate research skills or what role information literacy plays on workplace performance. The effect libraries have on graduates is not only of interest to librarians; the skills students gain in college have a significant impact on costs and productivity in the workplace. Within the last five years, the corporate world has acknowledged the importance of information literacy on workplace success. This has largely been linked to the growth of the knowledge management sector coinciding with the ability to access large amounts of unfiltered information on the internet.

The report, Are they really ready to work?: Employers' perspectives on the basic knowledge and applied skills of new entrants to the 21st century U.S. workforce (Casner-Lotto 2006) delineated $21^{\text {st }}$ century skills needed by baccalaureates. While information literacy was not specifically mentioned in the report, the areas of critical thinking/problem solving, information technology application, and lifelong learning certainly correspond to the ACRL standards. The following year, information literacy was listed as an Essential Learning Outcome by the Association of American Colleges and Universities (2007). The $A A C U$ (2007) states these outcomes, "reflect an important emerging consensus_-among educators and employers - about the kinds of learning needed for a complex and volatile world" (p. 13). Since then, variations of $21^{\text {st }}$ century skills have been increasingly adopted by universities to ensure their graduates possess the proficiencies needed to function in a knowledge-based society.
The purpose of this study is to examine various factors that may contribute to continued and sustained use of information literacy skills beyond the college experience, and specifically, what competencies students identify as essential for their work.

\section{Literature Review}

\section{Information Literacy in the Workplace}

The most significant research regarding information literacy in the workplace has been published by Christine Bruce (Bruce 1999; McMahon, C., \& Bruce, C., 2002). Using her seminal seven faces framework, Bruce examined information seeking behaviors in the workplace. Seven faces of information literacy in the workplace were identified: using information technology for awareness and communication; finding information from appropriate sources; executing a process; controlling information; building a personal knowledge base in a new area of interest; working with knowledge and personal perspectives to gain novel insight; and using information wisely for the benefit of others (Bruce, 1999). What is underscored is the importance of lifelong learning and the position information literacy has in all work sectors, not solely knowledge management. In 2002, Carmel O'Sullivan surmised that the term information literacy is "at best sporadic outside the isolation of the library and teaching professions". (p. 7) O'Sullivan also found that the corporate literature that did exist regarding informationgathering in the workplace focused on computer literacy or was framed in the context of lifelong learning. Other research laid the groundwork linking information literacy and knowledge management (Hughes, Middleton, Edwards, Bruce Mcallister, 2005; Kirton and Barham 2005; O'Farril 2008; Ferguson, 2009). Lloyd examined

Education Libraries, Volume 34, Number 2, Winter 2011 
information literacy through the lens of sociocultural practice, specifying the ranges of information modalities involved within the context of work (Lloyd 2007). Lloyd conducted studies that examined the work of ambulance drivers and firefighters and questioned whether the information literacy skills in the traditional settings of education and in the library had the same characteristics as the workplace (Lloyd 2008).

Studies that have quantified information literacy skills in the workplace focus mainly on current practices of employees and corporate needs (Smalley, 2000; Cheuk 2008). Using Bruces' seven faces framework(1999), Cheuk modeled an approach for information literacy training of employees at a large consulting firm (2008). For obvious reasons, professions that deal with the collection and creation of written product are more likely to be engaged in information gathering. However, as the importance of evidence-based practice has become a staple in medical fields and other on-the-job decision making, information literacy can conceivably be important in many other work environments.

As the body of information literacy research has expanded, several perspectives in the context of work have emerged (Halford, Lotherington, Obstefelder and Dyb 2008; Hepworth and Smith, 2008; Somerville and Howard, 2008; Klusek and Bournstein 2006). Again the focus has been on information-dependent professions. However, from the literature one key point emerges. Information seekers in the workplace require more advanced navigation and evaluation skills since often they do not have information experts to rely on nor do they always have access to vetted information sources like databases and knowledge management systems (Bruce, 1999; Lloyd , 2008; Ochs, 1991).

Assessing the transferability of information literacy Information literacy has been extensively evaluated in the K-16 settings. Standardized tests and various direct assessment tools have been developed to determine which skills students have mastered and attempt to measure the impact of information literacy skills or usage of library materials on academic success (Oakleaf and Owen 2010; de Jager 1997; Schulte, 2008; Shepherd 2011; Walsh
2011; Whitemire 2002; Wong 2011). What is lacking in the literature is a focus on what information competencies in the academic setting transfer to the workplace.

While previous research advocates collaboration between business managers and librarians to align information literacy with corporate needs, very few have tried to correlate the skills learned in college with actual use in the workplace. The most applicable methodology to use for such research is referred to as postcampus assessment (Rockman, 2002). This form of assessment measures the degree of skills students retain from their college research experience. Additionally, it helps identify which skills students and their employers' value. Ilene Rockman notes, "this post campus assessment technique can be used for gaining valuable feedback about the usefulness and applicability of course content, instructional strategies, and the campus learning environment" (p. 193). Three studies have employed this form of data collection to analyze the transferability of information seeking skills of alumni (Smalley 2000; Crawford and Irving 2006; $\mathrm{Wu}$ 2008). One of the earliest examples of this data collection technique was conducted by Ochs (1991). Ochs distributed surveys to both employers and alumni regarding use of information literacy and technology skills. Employers identified skill levels they expected of students while alumni rated their own skill set and where they felt they gained them. Of the most frequently identified sources of skill attainment, "“Cornell classes" or "on the job" and "on my own" often rate higher than Mann library instruction program as students' sources of information management skills" (p. 17). Ochs surmised that it was probably due to lack of librarian contact time with students. Another "postcampus" survey by Crawford and Irving (2006) was conducted after the widespread use of the internet in libraries. Alumni from Glasgow Caledonian were asked to identify which skills and to what extent research skills gained as students applied to their current workplace activities. The findings indicated that students felt the research skills they used in the university made a significant impact on their job performance. 
These results raise a core issue that libraries struggle to substantiate: what impact does information literacy really have on students, especially once they no longer have to conduct research for courses?

\section{Models of Information Literacy Instruction}

While most institutions strive for the perfect combination of tiered, embedded, curricular integration at the programmatic level, the reality is usually far removed. Stephanie Sterling Brasely examined models of information literacy in academic institutions and described the landscape as "collaborations that run along a continuum from the informal and episodic or scattershot to the formal, sequential, and programmatic." (Brasley, 2008, p. 77). Sue Curzon defined various models of information literacy integration including general education; credit courses; online tutorials; facultyled; and the most common, on-demand instruction (Curzon 2004). These models can be divided into two categories: direct and indirect information literacy instruction. Direct information literacy is curriculum-centric and either manifested as a requirement for graduation and integrated systematically at the university level. Indirect information literacy instruction is defined as librarycentric and not fully diffused into the curriculum but rather intermittently throughout the university. Typically, the latter model may have an instruction plan adopted by the library; however, without curricular requirements, there is no full integration of information literacy outcomes at the university level. Very few institutions of higher education have the "perfect" model of information literacy nevertheless; several examples of direct and indirect information literacy programs exist. Perhaps one of the first examples of a systematic approach to building more direct information literacy instruction is found in the California State University System. The California State University (CSU) system has had an advantage in the area of information literacy in large part due to a centralized approach to integration. The report Information Competence in the CSU (1995) developed a blueprint for providing financial and institutional support at individual campuses for inclusion of information literacy into the curriculum. Rockman (2002) described a multicampus approach that focused on providing grants, interdepartmental and cross-campus collaboration as well as faculty development opportunities. The approach was designed to take advantage of the trends in general education (GE) reform. The result was to enable many campuses in the system to create various configurations of information literacy instruction. Currently, half the libraries in the CSU System "have information literacy and competency learning outcomes as part of the institutional requirements for general education" (Travis, 2008, p. 18). The models that have been adopted at various CSU campuses can be categorized as both indirect and direct. Some examples of direct information literacy inclusion are CSU Northridge and CSU Los Angeles. Both have information literacy requirements for graduation which are fulfilled through GE courses. These are courses which are seamlessly embedded in course content, rather than a stand-alone tutorial, instruction session, or assignment. Other libraries in the system provide examples of indirect forms of information literacy integration. For example, Sonoma State has infused the first-year program with information literacy outcomes. CSU Long Beach has adopted information literacy outcomes for general education; however, there is currently no requirement in place for graduation. CSU Monterey Bay offers majors which have information literacy outcomes built into the overall departmental outcomes. Still other schools like San Diego State have established library instruction programs but no embedded information literacy curriculum. In many cases, a variety of information literacy integration can exist on the same campus. For example, CSU Long Beach has GE outcomes, some departmental outcomes, as well as faculty led information literacy instruction (Brasley, 2008). With such varying campuses and multi-pronged efforts, it is important to assess which models may have a greater or lesser impact on skills of alumni in the workplace.

Due to the variety of information literacy programs in existence, it is expected that student use of information literacy skills in the workplace will vary depending upon the method of information literacy integration. By comparing alumni from campuses with and without information literacy requirements, this study will explore the following research questions: 
RQ1: Does an information literacy requirement at a campus effect research skills?

RQ2: Do alumni attribute their information literacy skills to the library or other aspects of their education?

RQ3: How much do information literacy skills learned in college impact their use in the workplace?

\section{Background \& Methodology}

The model for this research study is based on the work of Crawford and Irving (2006). To modify the original survey for distribution in the United States, the language was changed from British to American English; questions were adjusted to current internet use trends; and a question about LEAP $21^{\text {st }}$ century skills was added. These skills identified by Association of American Colleges and Universities have recently been adopted by the CSU system in the revision of the GE curriculum (CSU, 2008) and mirror similar GE curriculum revisions nationwide. Part of this study examined which of the $21^{\text {st }}$ century skills participants identified as learning during college.

The instrument contained forty three questions divided into five sections (figure 1):

Figure 1: Five sections of the instrument.

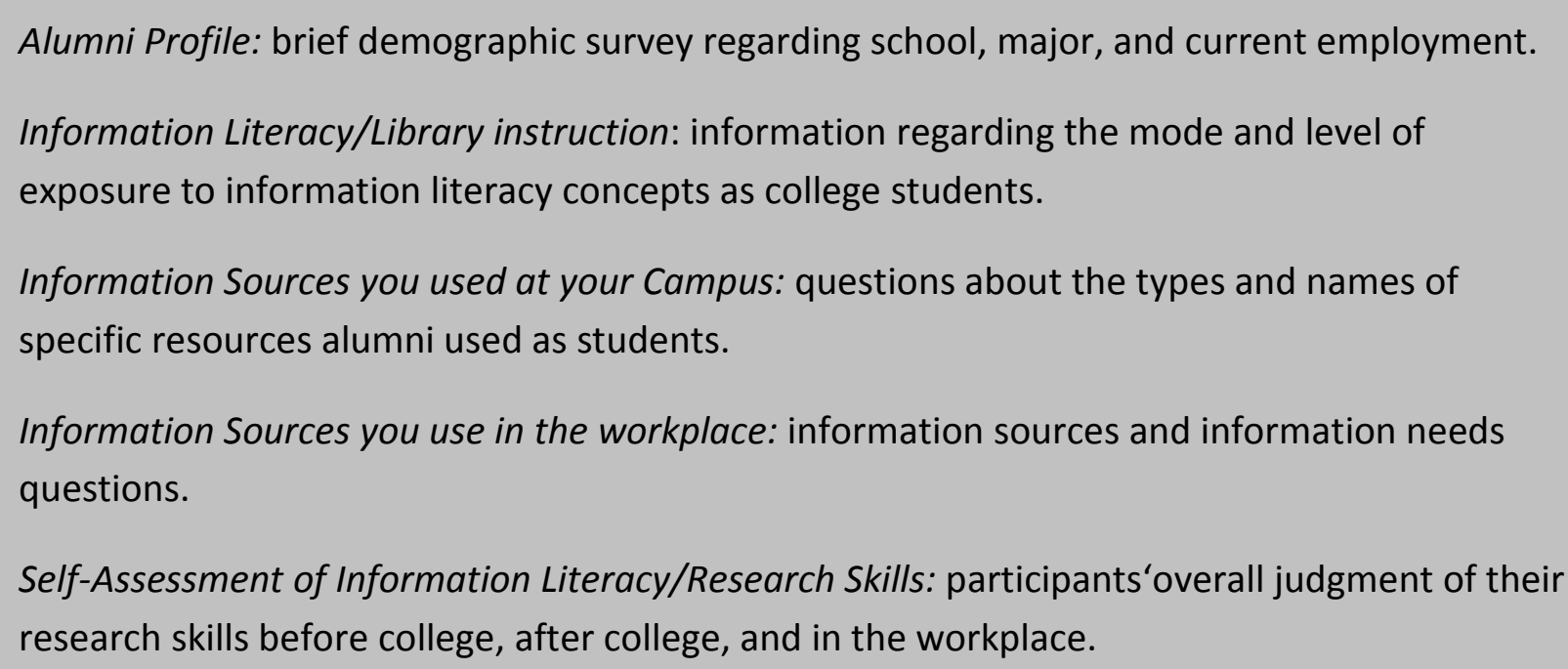

The purpose of this study was to:

- determine the extent to which graduates use information literacy/research skills in the workplace

- Explore any impact different models of information literacy curriculum integration has on these skills

- Compare differences between use of information sources for academic and workplace research

- Evaluate the distinction alumni make between research skills learned as college student with current research skills in the workplace.

\section{Results: Key Findings}

Demographics

In order to examine any patterns that may exist, the data was analyzed by population. Due to the low response rate, the results can only be used as a starting point of the discussion of the impact information literacy has on performance in the workplace and cannot be used to generalize all alumni experiences. This convenience sample provides descriptive data that can give insight into how information literacy has impacted respondents after they become members of the workforce.

The survey was distributed twice. The first dissemination was to graduates of the CSU system 
and the second was open to anyone that attended a four-year institution in the United States. There were 62 surveys started by CSU respondents with 54 usable surveys. There were 71 surveys started by the non-CSU respondents with 44 usable surveys. Eleven different CSU campuses were represented while over 24 campuses overall made up the total. Fifty-one percent of total respondents obtained master's degrees with less than one percent getting a $\mathrm{PhD}$. The disciplines for undergraduates were varied with most of the students majoring in social science programs, arts \& humanities, followed by business, and the sciences. The core numbers of graduates responding to the survey were psychology and library science degree holders with social sciences, education, business administration, social work and nursing respondents as well.

The majority of the respondents were female (71\%). $58 \%$ of the respondents could be described as Millenials (born between the ages of 1980-2000) while next largest age group were between the ages of 31-40.

RQ1: Does an information literacy requirement at a campus make a difference in research skills?

The data was examined to determine if there were significant differences between the populations that fulfilled information literacy requirements with those that did not. From the data collected the results are mixed. Twenty-eight percent of respondents answered that they had an information literacy requirement. Forty-nine percent had no requirement while $23 \%$ couldn't remember if they had such a requirement. Of the $28 \%$ who had a requirement, a surprising $85 \%$ satisfied the requirement by completing a credit course. Six percent of those who indicated that they had information literacy (IL) requirements in college listed their most advanced degree as library science. Eleven percent of those who responded they had no information literacy requirement or didn't remember also identified their highest degree as library science.

When comparing specific questions related to research there were no major differences in their self-rating of information literacy skills (Figure 2 and Figure 3). The students who attended college without an IL requirement were more confident in their skills both before and after college. This furthers the implication that students feel research skills increase as a result of attending college.

Figure 2

\begin{tabular}{l|ccc}
$\begin{array}{l}\text { Before starting my coursework at a 4-year College/University, my information } \\
\text { literacy/research skills were: }\end{array}$ & $\begin{array}{c}\text { IL Required } \\
\text { Response } \\
\text { Percent }\end{array}$ & $\begin{array}{c}\text { IL Not Required } \\
\text { Response Percent }\end{array}$ \\
\hline Answer Options & $19 \%$ & $19 \%$ & \\
\hline & $44 \%$ & $41 \%$ & \\
Poor & $33 \%$ & $29 \%$ & \\
Average & $3 \%$ & $10 \%$ & \\
Good & & & N=95
\end{tabular}


Figure 3

When I completed my coursework at a 4-year College/University my information literacy/research skills were:

\section{Answer Options}

Poor

Average

Good

Very good
IL Required

Response

Percent

$0 \%$

$15 \%$

$48 \%$

$37 \%$
IL Not Required

Response Percent

$0 \%$

$9 \%$

$39 \%$

$52 \%$

Another area of the survey where there was an expected difference was in responses to the questions regarding evaluation and application of information (Figure4).

Figure 4

Please mark all of the statements that best apply to you.

\section{Answer Options}

I use advanced search options when I search online resources.

I use advanced search options when I search subscription databases.

I use specific criteria for evaluating information I find using Internet information sources.

I use more than one source to verify the accuracy of information I find using Internet information sources. I regularly manipulate or otherwise incorporate information I find using Internet information sources into presentations or reports for work.

\section{IL Required \\ Response \\ Percent}

$84 \%$

$72 \%$

$52 \%$

$76 \%$

$40 \%$
$41 \%$

\section{IL Not \\ Required \\ Response \\ Percent}

$75 \%$

$69 \%$

$75 \%$

$81 \%$

$\mathrm{N}=89$

Most respondents stated they used advanced searching features when using the internet but less in subscription databases. The criteria they list for finding websites offers insight into what criteria is used to select sites found on the internet (Figure 5). 
Figure 5

When searching for information, how do you select which sites to use? Please mark all that apply.

\section{Answer Options}

I am already familiar with the site

URL listed for the site.

Information has been rated by other users.

Information is contrary to what I think.

See what sources the author used.

If the source is listed on the first page of search

results.

Consult the credentials listed for the author(s).

Information confirms my assumptions.

Site is well designed and easy to use.

I was referred to the site by a colleague or friend.

\section{IL Required}

Response Percent

$81 \%$

$23 \%$

$15 \%$

$4 \%$

$58 \%$

$27 \%$

$50 \%$

$4 \%$

$50 \%$

$69 \%$
IL Not Required

Response Percent

$87 \%$

$30 \%$

$19 \%$

$12 \%$

$67 \%$

$19 \%$

$48 \%$

$16 \%$

$60 \%$

$76 \%$

$\mathrm{N}=93$

Being familiar with a site and a referral to a site were the highest-ranking responses. Other findings regarding information-seeking behavior and undergraduates mirrors these results (Head \& Eisenberg 2010). It is interesting to note that "information has been rated by other users" is significantly lower than other referral-type answers due to the prevalence of user-generated rankings on sites such as Amazon, Yahoo Answers and Yelp.

Site design, while often identified in the literature as the least reliable way to evaluate site content, is still ranked by $50 \%$ or more of respondents, equal to credentials of the author. Selecting a source because it's on the first page of results is also a significant finding and should be investigated further to determine which search engines are being used and if there is any user understanding of how page rankings are calculated.

Also notable is the low number of respondents who regularly manipulate or incorporate information as part of their job (Figure 4). It begs to question what they do with the information they find in the workplace, especially when reports and presentations were ranked highest in response to the question "for which work related projects did you perform research to complete."

\section{RQ2: Do alumni attribute their information literacy skills to the library or other aspects of their education?}

\section{Information Literacy exposure}

The results for questions relating to information literacy exposure were very revealing. Sixty-eight percent of those who had no IL requirement recall attending a library-led research session. Sixty-three percent of those with no course-related interaction with librarians stated they consulted with librarians at some point in their career. Of those that had, $97 \%$ stated they got help at the reference desk with $29 \%$ using email and 5\% using instant message.

In terms of conducting research while attending university, $67 \%$ answered they used the library website to access information "often" with $18 \%$ responding "seldom" or "never". Thirty-nine percent replied they used the print collection "often" with $32 \%$ responding "seldom" or "never". All respondents affirmed using research databases in college. Seventy-six percent of respondents agreed with the statement "research databases were very important for completing my academic research." Fifteen percent disagreed or strongly disagreed with this statement. 
Figure 6

Library's subscription research databases (e.g. Lexis Nexis, Academic Search Elite, JSTOR etc.) were very important for the completion of my academic research.

\section{Answer Options}

\begin{tabular}{|l|c|}
\hline Strongly agree & $53 \%$ \\
\hline Agree & $23 \%$ \\
\hline Neutral & $9.0 \%$ \\
\hline Disagree & $4 \%$ \\
\hline Strongly disagree & $11 \%$ \\
\hline & \\
\hline
\end{tabular}

When asked what respondents felt contributed most to developing information literacy skills in college the results were interesting. "Writing research papers" and "figuring it out myself" were cited most often with "using the library resources" referenced by $55 \%$ of respondents (figure 7 ). Librarians were ranked 8 th below "professors" and "general education" as resources. "Library instruction," "credit courses by the library," and "online research tutorials" ranked lowest on the list. These findings from the study are reminiscent of Ochs' (1991) finding that "Cornell courses" and "on my own" ranked higher than library instruction.

Figure 7

What do you feel contributed most to developing your information literacy/research skills in college?

\begin{tabular}{|l|c|}
\hline Task & All respondents \\
\hline Writing research papers & $84 \%$ \\
\hline Figuring it out myself & $70 \%$ \\
\hline Using library resources & $55 \%$ \\
\hline General education & $52 \%$ \\
\hline Professors & $49 \%$ \\
\hline Research methods course & $43 \%$ \\
\hline Curriculum in my major & $42 \%$ \\
\hline Librarians & $33 \%$ \\
\hline & $29 \%$ \\
\hline Fellow students & $27 \%$ \\
\hline Library instruction session(s) & $12 \%$ \\
\hline Online research tutorial & $0 \%$ \\
\hline Credit course offered by the library & \\
\hline
\end{tabular}

\section{$21^{\text {st }}$ Century and Information Literacy Skill Areas}

When asked to select LEAP $21^{\text {st }}$ century skills and specific information literacy concepts they felt they current used in the workplace, the answers had interesting implications for integrating these skills into the curriculum (Figure 8). 
Figure 8

As a result of attending a 4-year College/University, which skills do you think you gained from your college experience that you use most often in the workplace? (please mark all that apply)

\begin{tabular}{|l|c|}
\hline Skill Area & All Respondents \\
\hline Finding relevant information & $78 \%$ \\
\hline *Critical thinking & $78 \%$ \\
\hline Evaluating information & $69 \%$ \\
\hline *Problem solving & $65 \%$ \\
\hline *Oral communication & $64 \%$ \\
\hline *Writing & $61 \%$ \\
\hline Recognizing bias & $56 \%$ \\
\hline *Methods of inquiry & $48 \%$ \\
\hline *Quantitative reasoning & $48 \%$ \\
\hline *Teamwork & $47 \%$ \\
\hline *Intercultural competence & $42 \%$ \\
\hline Determining an information need & $40 \%$ \\
\hline *Social responsibility & $40 \%$ \\
\hline Using information ethically & $39 \%$ \\
\hline *Self-understanding & $36 \%$ \\
\hline *Creativity & $33 \%$ \\
\hline *Global awareness & $28 \%$ \\
\hline Information cycle & $13 \%$ \\
\hline & \\
& *Denotes LEAP $21^{\text {st }}$ century skill \\
\hline
\end{tabular}

Respondents felt that college helped them gain critical thinking skills and problem solving the most, with "oral communication" and "writing" identified by more than $50 \%$ of respondents. What they felt it helped the least was "global awareness," "creativity," and "self-awareness." This isn't surprising, as these concepts are not something people typically "learn" in a classroom or through a specific assignment or course.

Of the information literacy skills, "finding relevant information" and "evaluating information" were chosen most often; the "information cycle" and "using information ethically" ranked lowest. "Determining an information need," which previous research identified as the most difficult informationseeking task, was marked by only $40 \%$ of respondents (Head 2010).
RQ3: How much do information literacy skills learned in college impact use in the workplace? Research in the workplace

All Respondents

The transmission of information literacy skills to the workplace is also examined in this survey. Onethird of all respondents use research skills to perform job daily; 30\% weekly, and 19\% monthly. $10 \%$ never use research skills in the workplace.

The job occupations listed by respondents who never used their research skills in the workplace included servers, sales, correctional officer, counselor, and registered nurses. Most of these respondents also indicated they spent most of their work day away from the computer. All of these respondents in this category indicated their research skills were unchanged before and after attending college. 
Another indicator of the transferability of information literacy skills to the workplace setting are the responses indicating the evaluation and application of information into their work lives. Fifty-three percent believe their research skills played a role in getting hired for their current position, while $36 \%$ did not feel research skills played any role in their current employment. In the workplace, respondents were more likely to use free internet sources than subscription databases. Free sources most often cited in openended responses were Google, trade websites, education databases, PubMed, and blogs.
The most-cited types of information looked for at work were current news, empirical research, and statistics while office supplies and medical information ranked lowest. The most-often cited work-related projects were reports and presentations. Open-ended responses included computer fixes, lesson plans, design work, patient care, emergency preparedness, lab research, research help, engineering projects, patient diagnosis, images/graphics, and legal research (Figure 9).

Figure 9

\begin{tabular}{|l|c|}
\hline $\begin{array}{l}\text { What types of information do you typically search for in the workplace? (please check } \\
\text { all that apply) }\end{array}$ \\
\hline Answer Options & Response Percent \\
\hline Current news & $57 \%$ \\
\hline Empirical research & $46 \%$ \\
\hline Product information & $36 \%$ \\
\hline Statistics & $36 \%$ \\
\hline Other (please specify) & $30 \%$ \\
\hline Information for my supervisor & $27 \%$ \\
\hline Law & $24 \%$ \\
\hline Price comparison & $23 \%$ \\
\hline Medical & $22 \%$ \\
\hline Licensing information & $17 \%$ \\
\hline Software & $17 \%$ \\
\hline Travel & $14 \%$ \\
\hline Human resources & $12 \%$ \\
\hline Office supplies & $11 \%$ \\
\hline Employment ads & $10 \%$ \\
\hline
\end{tabular}

In terms of rating their current research skills, $51 \%$ of respondents reported their skills had "gotten better" while $31 \%$ responded "unchanged." Very few reported their skills as becoming worse, which corresponds with the finding that the majority of respondents were not interested in receiving continuing education to increase their informationseeking skills. Those that stated they would want more training identified "keeping up to date" as their justification.

\section{Discussion}

The results of this study offer insights for both librarians and the corporate world. When comparing results to Crawford and Irving, there are similarities. In the Crawford study, the majority of alumni also believed research skills improved as a result of attending a university and felt their research skills improved once they were employed. In related research of Millennials (individuals born between 1980-2000) at work, it was reported that $77 \%$ of respondents felt that" technology helps me 
improve my work". In the same study $76 \%$ felt technology made them more successful in their career (O'Dell 2010). This study found $48 \%$ felt their information literacy skills were a factor for getting hired in their current position and $77 \%$ of respondents felt "finding information is an essential part of my work." This indicates the usefulness of information literacy skills in the workplace is acknowledged as much by graduates as it is by businesses.

Another study of information-seeking behavior of college students found most turned to friends $(87 \%)$ for help while only $14 \%$ asked librarians for assistance (Head \& Eisenberg 2010). Likewise, the results of the present study indicate this pattern of help-seeking continues after graduation. Of note in this study was the large number of students who consulted librarians in person $(97 \%)$ versus via email $(27 \%)$. The increased access to instant messaging and services such as LibAnswers may impact help-seeking patterns and deserves further research due to the visibility of the products and growing usage of both library services

The findings regarding evaluation of information can provide insight into areas that should be studied further. The number of students using "site design" to assign credibility to a website is troubling. Alison Head and Michael Eisenberg found similar results as $71 \%$ use interface design as part of their source selection (2010). There is also prevalence for alumni to use previous knowledge of a site as selection criteria. What should be examined is how individuals balance previous site content with new information needs. Research has found that students will select sites based on previous success regardless of if it appropriate for the topic. If this tendency continues after college, it may have implications, as librarians are not regularly employed in the workplace environment.

Another important aspect of the findings is the low ranking of librarians, online tutorials, and library instruction sessions as contributing to the growth of information literacy skills. What was identified most were tasks that required demonstrated use of information literacy concepts. "Writing research papers," "figuring it out myself," and "using library resources" are all active learning processes.
Itappears significant that students rated doing research contributed more to gaining which skills rather than passive learning activities such as sitting through a presentation or using an online tutorial. This strengthens the argument that information literacy should be embedded in courses and assignments rather than as a stand-alone or one-shot model.

Any research conducted to see how individuals interact with information and employ information literacy skills can be used to strengthen our instruction programs. The results of this study cannot definitively determine if an information literacy requirement is the best method to approach this. However, the results indicate that students are employing research skills in the workplace; they value and use library resources; and most importantly, they value the skills they gain from engaging in the finding, evaluating and applying information. As Bruce (1999) eloquently states, librarians need to "find ways to help learners reflect on their use of information, so that they become aware of their experiences and transfer these ways of working to a wide range of situations" (p. 45). This concept of transferability not only applies to work but to contribute to a society of lifelong learners.

\section{Limitations and Future Directions}

This study had several limitations. Initially, this survey was designed to be distributed only to alumni of the California State University system. This would have allowed the research to focus on known models of information literacy, and also allow for a comparison between direct and indirect information literacy programs. The low response rate made this comparison impossible, therefore it was distributed via social media outlets (Twitter, Facebook, listservs, etc.) to a nationwide audience. The issues with distributing the survey via social media meant a disproportionate amount of respondents had library science degrees and a population that regularly uses the internet for socializing. Any future studies should be distributed to a broader, diverse population.

In addition, future research should focus on examining the different information literacy skills 
between students who have completed credit courses versus those who have had no formal library instruction. While it is impossible to control for other sources of information literacy skill building, longitudinal studies examining participants both in the university and workplace settings will provide greater insight. The results of this study suggest there are other sources outside of library instruction where students feel they gain research skills that should be examined further.

Additionally, comparing knowledge management professions with less information-intensive professions would further define the differences in use of information by the two groups. Using a combination of outcomes based measures and phenomenography, data can be compiled to provide a definitive assessment of the libraries role in preparing individuals for lifelong learning.

\section{References}

Association of American Colleges and Universities., \& National Leadership Council (U.S.). (2007). College learning for the new global century: A report from the National Leadership Council for Liberal Education \& America's Promise. Washington, D.C: Association of American Colleges and Universities. Available: http://www.aacu.org/leap/documents/Global Century final.pdf

Association of College and Research Libraries., \& American Library Association. (2000). Information literacy competency standards for higher education. Chicago, IL: ACRL.

Brasley, S. (2008). Effective librarian and discipline faculty collaboration models for integrating information literacy into the fabric of an academic institution. New Directions for Teaching and Learning, 114, 71-88.

Bruce, C. S. (1999). Workplace experiences of information literacy. International Journal of Information Management, 19, 33-47.

California State University. California State University retools general education courses to focus on core values of liberal Education (Press Release) Available at http://www.calstate.edu/pa/news/2008/leap.s $\underline{\mathrm{html}}$

California State University. (1995). Information competence in the CSU: A report submitted to Commission on Learning Resources and Instructional Technology Work Group on Information Competence. Sacramento, CA: California State University.

Casner-Lotto, J., Conference Board., Partnership for 21 st Century Skills., Corporate Voices for Working Families., \& Society for Human Resource Management (U.S.). (2006). Are they really ready to work?: Employers' perspectives on the basic knowledge and applied skills of new entrants to the 21st century U.S. workforce. United States: Conference Board.

Cheuk, B. (2008). Delivering business value through information literacy in the workplace. Libri, 58. 137-143.

Crawford, J. (2006). The use of electronic information services and information literacy: A Glasgow Caledonian University study. Journal of Librarianship \& Information Science, 38(1), 33-44. doi: $10.1177 / 0961000606060958$

Curzon, S. C. (2004). Developing faculty-librarian partnerships in information literacy. In Rockman, I. F. (Eds.). Integrating information literacy into the higher education curriculum: Practical models for transformation. San Francisco: Jossey-Bass.

de Jager, K. (1997). Library use and academic achievement. South African Journal of Library \& Information Science, 65, 26-30.

Ferguson, S. (2009). Information literacy and its relationship to knowledge management. Journal of Information Literacy, 3, 6-24.

Halford, S., Lotherington, A. T., Obstfelder, A., \& Dyb, K. (2010). Getting the whole picture? Information, Communication \& Society, 13, 442-465.

Head A., Eisenberg M. (2010) Truth be told: How college students evaluate and use information in the digital age. Project Information Literacy Progress Report. Available http://projectinfolit.org/pdfs/PIL_Fall2010 Survey FullReport1.pdf

Education Libraries, Volume 34, Number 2, Winter 2011 
Hepworth, M., \& Smith, M. (2008). Workplace information literacy for administrative staff in higher education. Australian Library Journal, 57 , 212-236.

Hughes, H. , Middleton, M. , Edwards, S. , Bruce, C. and McAllister, L. (2005) Information literacy research in Australia 2000 2005, Bulletin des Bibliothèques de France 50, 1-23. Available http://eprints.qut.edu.au/archive/00002832/0 1/BdesB submission.pdf

Kirton, J., \& Barham, L. (2005). Information literacy in the workplace. Australian Library Journal, 54, 365-376.

Klusek, L., \& Bornstein, J. (2006). Information literacy skills for business careers: Matching skills to the workplace. Journal of Business \& Finance Librarianship, 11, 3-21.

Lloyd, A. (2007). Recasting information literacy as sociocultural practice: Implications for library and information science researchers. Information Research, 12, 1-13.

Lloyd, A. (2009). Informing practice: Information experiences of ambulance officers in training and on-road practice. Journal of Documentation, 65, 396-419.

McMahon, C., \& Bruce, C. (2002). Information literacy needs of local staff in cross-cultural development projects. Journal of International Development, 14, 113-127.

Oakleaf, M., \& Owen, P. L. (2010). Closing the 12 13 gap together: School and college librarians supporting 21 st century learners. Teacher Librarian, 37(4), 52-58.

Ochs, M. (1991). Assessing the value of an information literacy program. Ithaca, NY: Cornell University. ERIC EDRS340385. Available http://www.eric.ed.gov/PDFS/ED340385.pd f

O’Dell, J. (February 9, 2010) How millenials use tech at work. Read Write Web. Available http://www.readwriteweb.com/archives/how millenials use tech at work.php

O'Farril, R. T. (2008). Information literacy and knowledge management: Preparations for an arranged marriage. Libri: International Journal of Libraries \& Information Services, $58,155-171$.
O'Sullivan, C. (2002). Is information literacy relevant in the real world?. Reference Services Review, 30, 7-14.

Rockman, I. F. (2002). Strengthening connections between information literacy, general education, and assessment efforts. Library Trends, 51 185-98.

Schulte, S. J. (2008). High self-efficacy and high use of electronic information may predict improved academic performance. Evidence Based Library \& Information Practice, 3, 35-37.

Shepherd, P. T. (2011). Journal usage factor - a promising new metric. Serials, 24, 64-68.

Somerville, M. M., \& Howard, Z. (2008). Systems thinking: An approach for advancing workplace information literacy. Australian Library Journal, 57, 257-273.

Smalley, T. (2000). Investigating information age realities in the world of work. Available http://www.cabrillo.edu/ tsmalley/WorldOf Work.html

Travis, T. (2008). Librarians as agents of change: Working with curriculum committees using change agency theory. New Directions for Teaching and Learning, 114, 17-33.

Walsh, T. R. (2011). Evolution of an information competency requirement for undergraduates. Journal of Web Librarianship, 5, 3-23.

Whitmire, E. (2002). Academic library performance measures and undergraduates' library use and educational outcomes. Library \& Information Science Research, 24, 107-128.

Wong, S. H. R., \& Webb, T. D. (2011). Uncovering meaningful correlation between student academic performance and library material usage. College \& Research Libraries, 72, 361-370.

Wu, D. (2008). Aligning information literacy with workplace expectations. $12^{\text {th }}$ Biennial CARL Conference. Irvine, CA.

Tiffini A. Travis Director of Information Literacy \& Outreach Services, University Library California State University, Long Beach

Voice: 562- 985-7850

Fax: 562-985-1703

ttravis@,csulb.edu 